https://doi.org/10.30910/turkjans. 725793

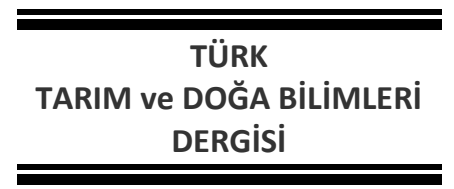

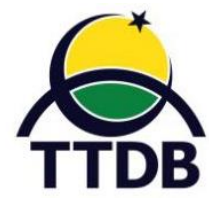

www.dergipark.gov.tr/turkjans

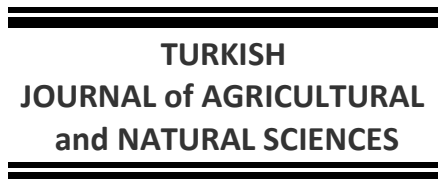

Araştırma Makalesi

\title{
Uşak ili Buğday (Triticum aestivum L.) Ekim Alanlarında Sorun Olan Yabancı Ot Türlerinin, Yaygınlık ve Yoğunluklarının Belirlenmesi ${ }^{*}$
}

\author{
Derya KÖKTAŞ ${ }^{1}$, Derya ÖĞÜT YAVUZ ${ }^{2 *}$ \\ ${ }^{1}$ Uşak Üniversitesi, Fen Bilimleri Enstitüsü, Tarım Bilimleri, Uşak \\ ${ }^{2} U$ şak Üniversitesi, Ziraat ve Doğa Bilimleri Fakültesi, Bitki Koruma, Uşak \\ *Sorumlu yazar: derya.ogutyavuz@usak.edu.tr
}

\section{Özet}

Geliş Tarihi: 27.08.2019 Düzeltme Geliş Tarihi: 08.12.2019 Kabul Tarihi: 04.02.2020

Yabancı otlar \% 48-52 oranlarında kayıpla diğer biyotik faktörlerden ön plana çıkmakta, rekabet ve salgıladığı allelopatik maddelerle buğdayda ürün kalitesinin düşmesine ve verim kaybına neden olmaktadır. Bu nedenle Uşak ili buğday alanlarında yürütülen bu çalışmada yabancı otların tür ve yoğunluklarının belirlenmesi, mücadele çalışmalarına kaynak oluşturması açısından önem arz etmektedir. Çalışma, Uşak ilini temsil edecek şekilde altı ilçede (Merkez, Banaz, Eşme, Karahallı, Ulubey ve Sivaslı) toplam 115 tarlada, mücadele yapılıp yapılmaması gözetilmeksizin buğday ekim alanları gezilerek yabancı otların tür, yaygınlık ve yoğunluklarının belirlenmesi amacıyla yürütülmüştür. Yapılan çalışma sonucunda Uşak ili buğday alanlarında 24 familyaya ait $11^{\prime} i$ cins, 65'i tür ve tür altı takson düzeyinde toplam 76 takson tespit edilmiştir. İl bazında elde edilen sonuçlara göre yabancı otların genel olarak yoğun olmadığı ancak bazı türlerin yaygın olduğu belirlenmiştir. Secale cereale L., Convolvulus arvensis L., Avena barbata Pott ex Link subsp. barbata, Galium tricornutum Dandy ve Bifora radians Bieb türleri en yaygın yabancı otlar olmuştur.

Anahtar Kelimeler: Uşak, Buğday, Yabancı otlar, Rastlama sıklığı, Yoğunluk, Survey

\section{Determining Species, Frequency, and Density of Weeds Species in Wheat (Triticum aestivum L.) Fields in Uşak Province}

\begin{abstract}
Weeds come into prominence among other biotic factors with a loss of $48-52 \%$ and it causes loss in production quality and yield loss in wheat with competition and allelopathic substances they release. For this reason, in this study conducted in wheat fields in Uşak province, determination of species and density of weed is important to form a reference for control studies. The study was conducted in a total of 115 fields in six districts (Center, Banaz, Eşme, Karahallı, Ulubey and Sivaslı) representing Uşak province by visiting wheat cultivation sites regardless of considering whether or not control is performed, in order to determine the species, frequency and density of weeds. As a result of the study, a total of 76 taxa which belonged to 24 families, 65 of which were at species and subspecies, 11 of which were at the genus level, were determined in wheat fields in Uşak province. Based on the provincebased results, it was determined that weeds did not have density in general, but some species were widespread. Secale cereale L., Convolvulus arvensis L., Avena barbata Pott ex Link subsp. barbata, Galium tricornutum Dandy and Bifora radians Bieb species were the most widespread weeds.
\end{abstract}

Keywords: Uşak, Wheat, Weeds, Frequency, Density, Survey 
Giriş

Buğday, insan besininin temelini oluşturması ve besinlerin ham maddesi olması açısından diğer tarımsal ürünlere oranla ayrı bir önem arz etmektedir. Poaceae familyasına ait tek yıllık, serin iklim bitkisi olan buğday ilk olarak Orta Asya'da bulunmuştur. Dünya'da yaklaşık 220 milyon hektar alanda yetiştirilmekte ve yaklaşık olarak bu üretimin yarısı, gelişmekte olan ülkelerde gerçekleştirilmektedir. Buğday yetiştiriciliği yapan başlıca ülkeler arasında Çin, Hindistan, ABD, Rusya, Fransa, Kanada, Almanya, Türkiye, Avustralya ve Ukrayna yer almakta olup (Nanher ve ark., 2015) 2010-2018 yılları arasında dünyada buğdayın ortalama 3.23 ton/ha verim, 715.051 milyon ton üretim ve 219.38 milyon hektar ekim alanına sahip olduğu görülmektedir (FAOSTAT, 2018). Ülkemizde tarımsal faaliyetler ve iklim koşullarına bağlı olarak bazı yıllarda, yıllık buğday üretiminin ülke ihtiyacının üzerinde olduğu, bazı yıllarda ise ülke ihtiyacını karşılayamadığı görülmektedir. Doğu ve Batı Karadeniz kıyıları ile Doğu Anadolu'nun yüksek kesimleri dışında Türkiye'nin her yerinde buğday üretimi yapılmakta bununla beraber; iç Anadolu Bölgesi \% 37, Güneydoğu Anadolu Bölgesi \%15, Marmara Bölgesi \% 11, Akdeniz Bölgesi \% 9 ve Ege Bölgesi \% 8'lik paya sahiptir (TÜik, 2017a). Uşak ili, geçiş iklim kuşağında yer alması nedeniyle gerek buğdayın kışlık yağışlardan faydalanması gerek olgunluğa ulaşması bakımından buğday için önemli bir ambar konumunda olup 2010-2018 yılları arasında ortalama $477.62(\mathrm{~kg} / \mathrm{da})$ oranında verime sahiptir.

Uşak, Ege Bölgesi'nin İç Batı Anadolu bölümünde bulunmaktadır. Akdeniz ikliminden karasal iklime geçiş özelliği ile daha çok Marmara iklimine benzemektedir. Yaz ve kış sıcaklıkları arasındaki fark oldukça yüksek olup geçiş iklimini yansıtan özelliklerin baskın olduğu bu bölgede, karasal iklim belirgin bir şekilde kendini hissettirmektedir (Kara ve ark., 2010). Bu özellikleri nedeniyle buğday yetiştiriciliği için önemli bir konumda olan Uşak'ta makarnalık buğday çeşitlerinden Çeşit 1252, Dumlupınar, Kızıltan 91; ekmeklik buğday çeşitlerinden ise Sönmez 2001 ve Nacibey yoğun olarak yetiştirilmektedir. Buğday, Uşak ilinde yetiştirilen kültür bitkileri içerisinde 658.122 da ekim alanı ve 161.942 ton üretim miktarıyla ilk sırada yer almakta ve ortalama $529 \mathrm{~kg} /$ da verim ile $563 \mathrm{~kg} /$ da olan Türkiye ortalamasının altında kalmaktadır (TÜik, 2017b). Buğday verimi üzerine birçok biyotik ve abiyotik faktörlerin etkileri görülmektedir. Hastalık etmenleri, zararlılar ve yabancı otlar buğdayda verim kayıplarına sebep olan (Oerke, 2005) biyotik faktörler içerisinde yer alıp, buğdayda yabancı otlar \% 48-52 oranında kayıpla diğer biyotik faktörlerden ön plana çıkmaktadır (Khan ve Haq, 2002). Rekabet ve salgıladığı allelopatik maddelerle buğdayda ürün kalitesinin düşmesine ve verim kaybına neden olmaktadır (Khaliq ve ark., 2012). Ayrıca yabancı otlar çimlenme ve gelişme için gerekli olan faktörler için rekabete girerek tahıl verimi ve kalitesini azalttı̆̆ı, mücadele maliyetlerini arttırdığı bildirilmiştir (Zimdahl, 2013). Yabancı ot-kültür bitkisi rekabetinden kaynaklı verim kayıplarının dünyada \% 15-20, Türkiye'de ise \% 20-35 oranında olduğu rapor edilmiştir (Yıldırım, 2008). Bu verim kayıpları ürün ve yabancı otların rekabet yeteneğine, yabancı ot türüne, iklim-toprak koşullarına ve bölgelere göre değişiklik göstermekte olup Ege Bölgesi'nde \% 30 (Bilgir, 1965), Doğu Anadolu Bölgesi'nde \% 22.5 ve Türkiye genelinde ise \% 27 olduğu bildirilmiştir (Güncan, 1982). Bu nedenle birim alandan elde edilen verim ve kalite düşüşünün nedenlerinden birinin de yabancı otlar ile mücadeledeki eksikliklerin olabileceği düşünülmektedir. Yağış alan veya sulama yapılan alanlarda yabancı ot tür sayısı, yoğunluğu ve mücadelesinde çeşitlilik yaşanmakta olup, özellikle topraktaki tohum rezervi ve tohumların dormansi sürelerinin farklılık göstermesi nedeniyle yabancı otların mücadelesinde zorluklar yaşanmaktadır.

Buğday ekim alanlarında, önemli verim kayıplarına sebep olan yabancı otlarla etkili mücadele yapabilmek için öncelikle bölgedeki yabancı ot florasının, türlerinin, yoğunluklarının ve rastlama sıklıklarının bilinmesi önem arz etmektedir. Bölgede hakim olan yabancı otların türleri, yoğunlukları ve rastlama sıklıkları ise Uşak ili için ilk kayıtları oluşturacak ve mücadeleye yönelik yapılacak olan çalışmalara yön verecektir.

\section{Materyal ve Yöntem}

\section{Araştırma Alanının Genel Özellikleri}

Uşak ili, Ege Bölgesinin İç Batı Anadolu bölümünde $28^{\circ} 48^{\prime}-29^{\circ} 57^{\prime}$ doğu boylamları ile $38^{\circ} 13^{\prime}-38^{\circ} 56^{\prime}$ kuzey enlemleri arasında yer almaktadır. il arazisi genel olarak dalgalı plato 
görünümünde olup kuzey ve doğu bölgeleri dağıık, güney ve batı bölgeleri ise ovalar ve dalgalı arazilerden oluşmaktadır. İklim özelliği bakımından Ege ve iç̧ Anadolu bölgeleri arasında geçiş özelliği göstermektedir. Baskın olarak karasal iklim görülmekte olup kışları uzun ve sert, yazları sıcak geçmektedir (Anonim, 2018a). Uşak ili aylık ortalama en yüksek sıcaklık $24.3^{\circ} \mathrm{C}$ ile Ağustos, ortalama en düşük sıcaklık ise $3.6{ }^{\circ} \mathrm{C}$ ile Ocak ayında ölçülmüştür. Yıllık ortalama yağış miktarı 584.9 mm'yi bulmakta ve bunun \% 37'ye yakın oranı kış mevsiminde düşmektedir. En fazla yağış ise
$92.9 \mathrm{~mm}$ ile Aralık ayında kaydedilmiştir. Surveyin gerçekleştirildiği yetiştiricilik dönemine ait iklim verilerine göre en düşük sıcaklık ve en yüksek yağış oranı sırasıyla -5.7 ${ }^{\circ} \mathrm{C}$; $62.1 \mathrm{~mm}$ değerleriyle 2018 Ocak ayında kaydedilmiştir. Bölge koşullarında en yüksek sıcaklık verileri ise buğdayın hasat döneminde Temmuz ayında $33.3{ }^{\circ} \mathrm{C}$ olarak belirlenmiştir. En kurak dönem ise $7.9 \mathrm{~mm}$ yağış miktarıyla Nisan ayında gerçekleşmiştir (Anonim, 2018b). Uşak ili sıcaklık, nispi nem ve yağış miktarına ait veriler Çizelge 1'de sunulmuştur.

Çizelge 1. Uşak ilinde 2017 ve 2018 yıllarına ait aylık sıcaklık, toplam yağış ve nispi nem değerleri

\begin{tabular}{|c|c|c|c|c|c|c|c|c|c|c|c|c|}
\hline Yıllar & Ocak & Şubat & Mart & Nisan & Mayıs & Haziran & Temmuz & Ağustos & Eylül & Ekim & Kasım & Aralık \\
\hline \multicolumn{13}{|c|}{ Aylık Minimum Sıcaklık $\left({ }^{\circ} \mathrm{C}\right)$} \\
\hline 2017 & -9.8 & -9.0 & -4.8 & 0.0 & 4.9 & 9.1 & 12.1 & 13.2 & 8.4 & 2.5 & -4.2 & -4.4 \\
\hline 2018 & -5.7 & -2.2 & -0.9 & 1.9 & 4.5 & 9.3 & 13.7 & 12.6 & 10.1 & -0.4 & -1.3 & -6.5 \\
\hline \multicolumn{13}{|c|}{ Aylık Maksimum Sıcaklık ( $\left.{ }^{\circ} \mathrm{C}\right)$} \\
\hline 2017 & 11.3 & 16.2 & 21.2 & 25.8 & 29.5 & 36.5 & 38.0 & 36.4 & 36.5 & 24.9 & 20.2 & 18.5 \\
\hline 2018 & 14.8 & 17.6 & 21.0 & 28.5 & 29.4 & 32.4 & 33.3 & 34.5 & 34.7 & 26.0 & 24.5 & 13.8 \\
\hline \multicolumn{13}{|c|}{ Aylık Ortalama Sıcaklık $\left({ }^{\circ} \mathrm{C}\right)$} \\
\hline 2017 & -0.1 & 4.2 & 8.3 & 11.0 & 15.1 & 20.0 & 25.3 & 24.0 & 21.6 & 13.1 & 7.5 & 5.7 \\
\hline 2018 & 3.6 & 6.7 & 9.3 & 15.3 & 17.2 & 20.2 & 23.7 & 24.3 & 20.7 & 14.9 & 9.6 & 3.7 \\
\hline \multicolumn{13}{|c|}{ Aylık Maksimum Yağış $\left(m m=k g \div m^{2}\right)$} \\
\hline 2017 & 10.2 & 3.4 & 18.0 & 16.3 & 19.0 & 5.4 & 2.2 & 7.4 & 26.2 & 15.3 & 14.0 & 8.8 \\
\hline 2018 & 21.9 & 12.0 & 13.9 & 5.2 & 15.4 & 20.8 & 11.6 & 18.0 & 0.1 & 45.0 & 18.0 & 21.7 \\
\hline \multicolumn{13}{|c|}{ Aylık Toplam Yağış $\left(m m=k g \div m^{2}\right)$} \\
\hline 2017 & 69.8 & 8.0 & 39.4 & 63.1 & 81.0 & 30.5 & 6.8 & 19.0 & 26.4 & 36.7 & 38.9 & 47.8 \\
\hline 2018 & 62.1 & 59.0 & 56.6 & 7.9 & 76.7 & 48.1 & 21.0 & 43.3 & 0.1 & 53.8 & 63.4 & 92.9 \\
\hline \multicolumn{13}{|c|}{ Aylık Minimum Nispi Nem (\%) } \\
\hline 2017 & 22 & 13 & 11 & 12 & 18 & 15 & 11 & 11 & 11 & 11 & 50 & \\
\hline 2018 & & 27 & 15 & 13 & 17 & 12 & 11 & 30 & 14 & 13 & 13 & 28 \\
\hline \multicolumn{13}{|c|}{ Aylık Maksimum Nispi Nem (\%) } \\
\hline 2017 & 97 & 96 & 97 & 96 & 95 & 95 & 90 & 88 & 93 & 97 & 72 & \\
\hline 2018 & & 97 & 98 & 95 & 97 & 95 & 95 & 94 & 86 & 96 & 98 & 98 \\
\hline \multicolumn{13}{|c|}{ Aylık Ortalama Nispi Nem (\%) } \\
\hline 2017 & 74.0 & 64.9 & 59.7 & 56.4 & 61.5 & 59.3 & 41.2 & 48.1 & 38.3 & 58.1 & 67.5 & 76.1 \\
\hline 2018 & 73.3 & 73.9 & 67.9 & 47.8 & 61.2 & 59.3 & 49.1 & 48.3 & 45.6 & 59.0 & 67.3 & 80.3 \\
\hline
\end{tabular}




\section{Yöntem}

Uşak ili buğday üretim alanlarındaki yabancı ot türlerini, yaygınlık ve yoğunluklarını belirlemek amacıyla, 2018 yılı üretim sezonunda survey çalışması yürütülmüştür. Uşak ilini temsil edecek şekilde ve 6 ilçede (Merkez, Banaz, Eşme, Karahallı, Ulubey ve Sivaslı) kuzey, güney, doğu ve batı yönlerinde her 2 km'de bir durularak rastlanan en yakın buğday tarlasına girilmiştir (Uygur, 1997). Uşak ilinde toplam 115 tarlada survey yapılmış olup, ekim alanının en az \% 1'ini temsil edecek şekilde örnekleme yapılmıştır (Özaslan ve ark., 2011). Ekim alanına (da) göre ilçeler bazında örnek alınan toplam tarla sayıları Çizelge 2'de belirtilmiştir. Kenar tesirinden kurtulmak amacıyla tarlanın biraz iç kısmından $1 \mathrm{~m}^{2 \prime}$ lik çerçeve 4 kez atılmış ve çerçeve içine giren yabancı ot türleri cins veya tür bazında teşhis edilerek her bir türe ait fert sayıları kaydedilmiştir (Uygur, 1985). Buğday ekim alanlarından alınan yabancı ot örneklerinin teşhisleri "Flora of Turkey and Eagean Island" adlı yayınlardan (Davis, 1965-1985; Davis ve ark., 1988; Güner ve ark., 2000)'e göre yapılmış ayrıca teşhisinde zorlanılan bitkiler için benzer çalışmalar yapan araştırmacılardan da yardım alınmıştır. Geniş yapraklı yabancı otlar bitki, dar yapraklılar ise sap olarak sayılmıştır. Survey çalışmaları sonucunda yabancı otların rastlama sıklığı (\%) ve yoğunlukları (adet $\mathrm{m}^{-2}$ ) Odum (1971)'a göre hesaplanmıştır. Odum (1971)'un popülasyon kriterlerinin belirlenmesi ile ilgili formülleri aşağıda belirtilmiştir.

$\mathrm{n}=$ Her türün rastlandığı ölçüm sayısı,

$m$ = Yapılan toplam ölçüm sayısı,

$\mathrm{b}=$ Alınan örnekte toplam birey sayısı

Rastlama Sıklığı (\%) = $100 \times \mathrm{n} / \mathrm{m}$

Yoğunluk = b/m

Survey yapılan tarlalarda belirlenen türlerin yaygınlık ve yoğunluk değerlerine göre sınıflandırılması ve önemli türlerin vurgulanması amacıyla farklı araştırmacılar tarafından geliştirilen veya revize edilen skala değerleri Uludağ (1993), Tepe (1989), Arslan (2018a) kullanılmıştır. Skala değerlerinin anlamları Arslan (2018a)'e göre değerlendirilmiştir. İlgili skala değerleri Çizelge 3'de belirtildiği şekildedir.

Çizelge 2. Survey yapılan Uşak ili merkez ve ilçeleri, buğday ekim alanları (da) ve örnek alınan toplam tarla sayısı.

\begin{tabular}{lcc}
\hline \multicolumn{1}{c}{ Survey Alanları } & Ekim Alanı (da) & $\begin{array}{c}\text { Örnek Alınan Toplam Tarla Sayısı } \\
\text { (adet) }\end{array}$ \\
\hline Merkez & & 42 \\
Ulubey & 225.714 & 13 \\
Eşme & 47.329 & 12 \\
Karahallı & 80.925 & 7 \\
Sivaslı & 41.131 & 13 \\
Banaz & 86.758 & 28 \\
Uşak (Toplam) & 176.265 & 115 \\
\hline
\end{tabular}

Çizelge 3. Türlerin yaygınlık ve yoğunlukları ile ilgili skala değerleri

\begin{tabular}{llllll}
\hline \multicolumn{3}{c}{ Yaygınlık (Uludağ, 1993) } & \multicolumn{3}{c}{ Yoğunluk (Tepe, 1989; Uludağ, 1993) } \\
\hline Ç & $: \geq \% 50$ & Çok yaygın & A & $\geq 10$ adet $\mathrm{m}^{-2}$ & Çok yoğun \\
Y & $\% 25-49$ & Yaygın & B & $5.00-9.99$ adet $\mathrm{m}^{-2}$ & Yoğun \\
O & $\% 13-24$ & Orta yaygınlıkta & C & $1,00-4.99$ adet $\mathrm{m}^{-2}$ & Orta yoğunlukta \\
$\mathrm{N}$ & $<\% 12$ & Düşük yaygınlıkta & D & $0.10-0.99$ adet $\mathrm{m}^{-2}$ & Düşük yoğunlukta \\
& & E & $0.01-0.09$ adet $\mathrm{m}^{-2}$ & Çok düşük yoğunlukta \\
& & F & $<0.01$ adet $\mathrm{m}^{-2}$ & Nadir \\
\hline
\end{tabular}




\section{Bulgular ve Tartışma}

Uşak ili merkez ve ilçelerinde 2018 yılı buğday üretim sezonu içerisinde ekim alanlarında görülen yabancı otların belirlenmesi amacıyla yürütülen çalışma sonucunda; 1 tanesi monokotiledon, 23 tanesi ise dikotiledon olmak üzere 24 familyaya ait $11^{\prime} i$ cins $65^{\prime} i$ tür ve tür altı takson düzeyinde toplam 76 takson tespit edilmiştir. Brassicaceae ve Asteraceae familyaları onar yabancı ot türüyle ilk sırada yer alırken, Apiaceae ve Poaceae familyaları sekizer tür ile ikinci, Fabaceae familyası beş tür ile üçüncü sırada yer almış olup tür sayılarının familyalara göre dağılımı Şekil 1'de sunulmuştur.

\section{Yabancı Ot Tür Sayıları (adet)}

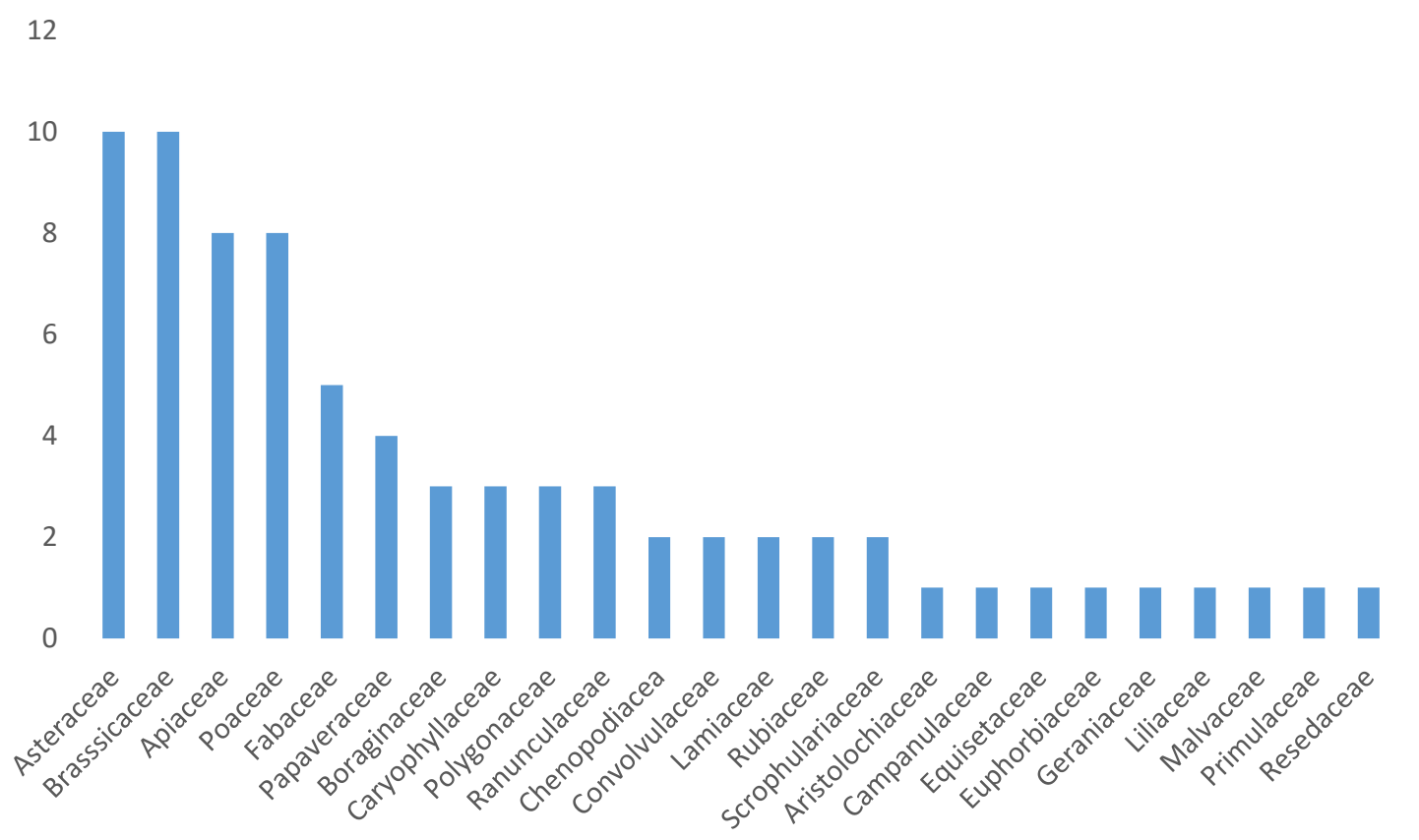

Şekil 1. Uşak ili merkez ve ilçelerindeki buğday ekim alanlarında yapılan survey sonucu elde edilen yabancı ot türlerinin familyalara göre dağılımı.

Survey sonuçlarına göre ilçelere bağı olarak yabancı ot türleri, yoğunlukları ve rastlama sıklığı oranlarında farklılıklar belirlenmiştir (Çizelge 4). Uşak ili merkez ve ilçelerinin geneline bakıldığında; 115 buğday ekim alanında belirlenen yabancı otlar içerisinde \% 85.22 rastlama sıklığıyla Secale cereale L. ilk sırada yer alırken bunu sırasıyla Convolvulus arvensis L. (\% 83.5), Avena barbata Pott ex Link subsp. barbata (\% 77.4), Galium tricornutum Dandy. (\% 60.9) ve Bifora radians Bieb. (\% 49.6) türleri takip etmiş ve skala değerlerine göre çok yaygın türler olarak belirlenmiştir. Echinophora tenuifolia L. subsp. sibthorpiana (Guss.) Tutin, Turgenia latifolia (L.) Hoffm., Anthemis arvensis L., Centaurea depressa Bieb., Vicia spp., Papaver rhoeas L., Polygonum aviculare L. ise rastlama sıklığı \% 25-49 arasında yer almış yaygın türlerdir. Yabancı otların yoğunlukları skala değerine göre $\geq 10$ adet $\mathrm{m}^{-2}$ (çok yoğun) ve
5.00-9.99 adet $\mathrm{m}^{-2}$ (yoğun) ele alındığında çok yoğun ve yoğun olarak kaydedilmiş türler bölgemiz florasında şu anki koşullarda mevcut değildir. Ancak orta yoğunluk 1.00-4.99 adet $\mathrm{m}^{-}$ ${ }^{2}$ değerleri arasında olan türler, S. cereale (3.98

adet $\left.\mathrm{m}^{-2}\right), A$. barbata Pott ex Link subsp. barbata (3.49 adet $\mathrm{m}^{-2}$ ), C. arvensis (2.28 adet $\mathrm{m}^{-2}$ ) ve $G$. tricornutum (1.88 adet $\mathrm{m}^{-2}$ ) olarak belirlenmiştir. Uşak ili Sivaslı, Merkez, Banaz ve Eşme ilçelerinde sırasıyla \% 100, \% 88, \% 85.7, $\% 83.3$ rastlama sıklığı ile ilk sırada yer alan $S$. cereale Türkiye'nin Doğu Anadolu Bölgesinde yapılan bazı survey çalışmalarında da ilk on sırada yer aldığı görülmektedir (Sırma ve Kadıoğlu, 2010; Gürbüz ve ark., 2018). Bu konuda Isparta ilinde buğdayda yürütülen çalışmada $S$. cereale ve $C$. arvensis rastlama sıklığı açısından ilk sırada yer alan türleri oluşturduğu (Kitiş ve Boz, 2003), Bayburt ilinde buğdayda yapılan başka bir çalışmada ise 
Fallopia convolvulus ve $S$. cereale türlerinin buğday tarlalarının baskın türü olduğu ifade edilmiştir (Kordali ve Zengin, 2007). Bu durumun genellikle karasal iklimin hakim olduğu kışları uzun ve sert geçen iklim benzerlik göstermektedir. Karahallı ve Ulubey ilçelerinde ise C. arvensis sırasıyla \% 100 ve \% 92.3 rastlama sıklığıyla hemen hemen her tarlada görünür, çok yaygın bir tür olarak dikkati çekmektedir. Bu durumun özellikle bu ilçelerde uzun süreli ekim nöbeti uygulamasının yapılamaması ve kuru tarım nedeniyle alternatif ürün olarak çoğunlukla nohutun ekim nöbeti sisteminde yer alan bitki olması $C$. arvensis'in hem hububat hem de nohut ekim alanlarında etkili kimyasal mücadelesinin olmayışı bu türün yaygın olarak görülebileceğini düşündürmektedir. Piyasada nohut alanlarında C. arvensis'in mücadelesinde bir preparatın olmayışı da bir sonraki yıl buğday için önemli bir tohum rezerv kaynağını oluşturarak türün rastlama sıklığı ve yoğunluğuna önemli oranda katkıda bulunmaktadır. Bu türün buğday üretim alanlarında önemli türler içerisinde yer aldığı da farklı araştırmacılar tarafından ortaya konulmuştur (Civelek ve ark., 1997; Boz ve ark., 2000; Kaya ve Zengin 2000; Kitiş ve Boz, 2003; Üstüner ve Altın, 2003; Töre, 2014; Gürbüz ve ark., 2018; Arslan, 2018b; Sırrı, 2019). S. cereale yoğunluk bakımından Karahallı, Eşme ve Sivaslı ilçelerinde sırasıyla; 10.9 adet $\mathrm{m}^{-2}, 7.4$ adet $\mathrm{m}^{-2}, 5$ adet $\mathrm{m}^{-2}$ ile ilk sırada yer alırken, Ulubey, Merkez ve Banaz ilçelerinde; 4.8 adet $\mathrm{m}^{-2}, 3.5$ adet $\mathrm{m}^{-2}, 3.6$ adet $\mathrm{m}^{-2}$ ile $A$. barbata Pott ex Link subsp. barbata ön plana çıkmıştır. illçelere göre yabancı ot türlerindeki farklılığın ekolojik faktörlere, yapılan tarımsal uygulamalara, tercih edilen buğday çeşitlerine, kullanılan tohum miktarı gibi bazı faktörlere bağlı olarak yabancı ot tür ve yoğunluklarında değişiklerin olabileceğini göstermektedir. Bölgemizde dekara kullanılan tohum miktarının fazla olması, genellikle geniş yapraklı yabancı ot mücadelesinde 2.4-D amin ve tribenuron methyl etkili maddeli herbisitlerin yaygın olarak kullanılıyor olması da dar yapraklı yabancı otların rekabetinin engellenmesinden dolayı daha baskın hale gelebileceğini düşündürmektedir. Tokat ili buğday ekim alanlarında yapılan çalışma sonucunda yabancı ot tür, yaygınlık ve yoğunluklarının ekolojik faktörler ile çiftçi uygulamalarından etkilenebileceği ifade edilmiştir (Töre, 2014). Rastlama sıklığı ve yoğunluk bakımından önemli olan yabani yulaf türleri dünyada ılıman tarım kuşaklarına sahip bölgelerde $S$. cereale'nin adaptasyon yeteneğinin iyi olduğu, mevcudiyetini devam ettirdiği ve buğday ekim alanlarının baskın türü olarak görüldüğü yapılan çalışmalarda da ifade edilmiş olup çalışmamızla bölgelerinde en çok zarar oluşturan yabancı otlarından biri olup yürütülen pek çok çalışmada yer almakta ve çalışmamızla benzerlik göstermektedir (Kadıoğlu, 1989; Kara, 1993; Boz, 2000; Holm ve ark., 2000; Boz ve ark., 2002; Tursun, 2002; Gökalp ve Üremiş, 2015). Tarım alanlarında olduğu gibi tarım dışı alanlarda da rastlanılan türlerinden biri olan $A$. barbata Pott ex Link subsp. barbata ülkemizde yürütülen çalışmalarda yer almıştır (Doğan ve ark., 2004; Çetin ve Seçmen, 2008; Cavlan ve Şık, 2012; Gider, 2013; Sargın ve ark., 2013; Satıl ve ark., 2016; Kılıç ve ark., 2018; Ersoy ve ark., 2019; Fener ve Aykurt, 2019). Bursa ili zeytin bahçelerinde yabancı ot türleri, yoğunlukları ve rastlanma sıklıklarının belirlenmesi amacıyla yapılan çalışmada 1.47 bitki $\mathrm{m}^{-2}$ ile $A$. barbata en yoğun on tür arasında olup \% 66 rastlama sıklığıyla yabancı ot türleri arasında dördüncü sırada yer almıştır (Tuğrul, 2013). Enez (Edirne) ve çevresinde tarım alanlarındaki yabancı ot florasının belirlenmesi amacıyla yürütülen çalışmada $A$. barbata Pott ex Link subsp. barbata buğday ekim alanlarında görülen yabancı ot türleri içerisinde yer almıştır. (Kireç ve Yarcı, 1998). Eskişehir ilinde farklı yıllarda yapılan çalışmalarda en fazla yabancı ot türlerinin bulunduğu ürünler sırasıyla; \% 39 oranla buğday, \% 25 oranla pancar, \% 14 oranla yonca ve \% 12 oranla diğer ürünlerin (mısır, nohut, sebze, meyve bahçeleri) olduğu belirtilirken, $A$. barbata Pott ex Link subsp. barbata'nın buğday alanlarında görülen bir tür olduğu ifade edilmiş ve çalışmamızla benzerlik göstermiştir (Türe ve Köse, 2000; Türe ve Böcük, 2007). Yine aynı bölgede tarım alanlarında yürütülen çalışmada 327 tür ve tür altı takson belirlenmiş olup yabancı otların bulundukları kültür bitkisine göre dağılımları ise buğday (186), şeker pancarı (102), arpa (44), kabak (37), nohut (33), domates (27), yulaf (17), mısır (16), biber (12) ve lahana (12) olduğu ve şekerpancarı üretim alanlarında görülen yabancı ot türleri içerisinde $A$. barbata Pott ex Link subsp. barbata'nın yer aldığı ifade edilmiştir (Söker ve ark., 2012). Yarcı ve Altay (2016), Kocaeli ve çevresindeki arpa, buğday, mısır ve yulaf ekim alanlarında yabancı ot florasının belirlenmesi amacıyla yürüttükleri çalışmada $A$. barbata Pott ex Link subsp. 
barbata buğday ve arpa alanlarında rastlanmış olup, en fazla takson içeren ilk üç familya ise sırasıyla Poaceae, Asteraceae ve Fabaceae olarak kaydedilmiş ve bu familyaların da çalışmamızda öne çıkan familyalar arasında olduğu görülmüştür. Uşak ili Eşme ilçesinin florasının belirlenmesi için yapılan çalışmada Fabaceae, Brassicaceae, Asteraceae ve Poaceae familyaları ön plana çıkmış ve $A$. barbata bölgede rastlanan türler arasında yer almıştır (Güler ve ark., 2013). A. barbata Pott ex Link subsp. barbata Marmara ve Ege bölgelerinde rastlandığı gibi Doğu Anadolu ve çevresinde de yaygın olarak görülen yabancı ot türü olarak tespit edilmiştir (Öztürk ve ark., 2015). G. tricornutum rastlama sıklığı ve yoğunluk açısından ilimizde önemli bir tür olduğu görülmekte ve diğer çalışmalarla benzerlik göstermektedir (Taştan ve Erciş, 1991; Uludağ, 1993; Sırma, 1995). Galium aparine'nin buğday da \% 0.7-2.9 oranında azalmaya neden olduğu (Wilson ve Wright, 1987) ve rastlama sıklığı açısından da ilk sıralarda yer aldığı (Karlıil, 1988; Boz ve ark., 2002) belirtilmiştir. Ülkemizde farklı bölgelerde yapılan çalışmalar sonucunda elde edilen veriler doğrultusunda buğday alanlarında benzer yabancı otların hakim olduğu görülürken, yaygınlık ve yoğunluklarındaki farklılıkların survey çalışmalarının yapıldığı bölgelerin ekolojik özellikleri, toprak yapısı, yetiştirilen ön bitki, tercih edilen çeşit, yapılan tarımsal faaliyetler gibi unsurlar tarafından etkilenebileceği ve baskın olan türler arasında farklılıkların olabileceği ifade edilmiştir (Uludağ, 1997; Özaslan ve ark., 2011; Töre, 2014; Pala ve Mennan, 2017; Önen ve ark., 2018; Sırrı, 2019). Örneğin Özaslan ve ark. (2011) tarafından Diyarbakır'da yürütülen bir çalışmada buğday ekim alanlarının \% 50'sinden fazlasında rastlanılan türler Avena sterilis, Sinapis arvensis, G. tricornutum, Cephalaria syriaca ve $C$. arvensis olarak belirtilirken, aynı ilde altı yıl sonra gerçekleştirilen surveyde Avena fatua, $S$. arvensis, $G$. aparine, $P$. rhoeas, Cirsium arvense yoğun olarak görülen türleri oluşturmuştur (Pala ve Mennan, 2017). Bu durum aynı ilde farklı zamanlarda yapılan çalışmalarda dahi baskın olan türler arasında farklılıkların olabileceğini sonuçta iklim koşulları ve yapılan tarımsal faaliyetlerin baskın olan türler üzerinde etkin rol oynadığını göstermektedir. Tokat ili buğday ekim alanlarında yürütülen başka bir çalışmada ise Stelleria media, Capsella bursapastoris, P. aviculare, G. aparine, Veronica hederifolia, S. arvensis, Avena spp., yaygınlık ve yoğunluk bakımından ilk sıralarda yer alan türler olmuştur (Töre, 2014). Kışlık buğday üretiminde Şanlıurfa'da yabancı ot florasının belirlenmesi amacıyla gerçekleştirilen çalışmada A. fatua, G. aparine, S. arvensis, Vaccaria pyramidata, Isatis tinctoria, Echinaria capitata ve Fumaria officinalis en yaygın yabancı otlar olarak belirlenmiştir (Bükün, 2004). Kahramanmaraş buğday alanlarında $A$. fatua $\left(2.29\right.$ adet $\left.\mathrm{m}^{-2}\right)$ ve $S$. arvensis $\left(3.24 \text { adet } \mathrm{m}^{-2}\right)^{\prime}$ in $\% 50^{\prime}$ nin üstünde yaygınlık ile en önemli yabancı otlar olduğu bildirilmiştir (Tursun, 2002). Sonuçta ülkemizde farklı bölgelerde yapılan çalışmalarda farklı yoğunluklarda yabancı otlar belirlemiş olup, ilimiz koşullarında buğday alanlarında yabancı otların yoğun olarak bulunmayışı sevindirici olmakla birlikte bazı türlerin yaygın olması ileriki dönemlerde etkili mücadele önlemlerinin alınmaması durumunda önemli kayıpların yaşanabileceğini ifade etmektedir. il genelinde üreticilerin çoğunluğunun kullanılan tohumluk miktarını 26$30 \mathrm{~kg} / \mathrm{da}$ olarak uygulaması da genel olarak yabancı ot yoğunluğu üzerinde etkili olabileceğini düşündürmektedir. Söz konusu yabancı otlardan S. cereale (3.98 adet $\mathrm{m}^{-2}$ ) ve $A$. barbata Pott ex Link subsp. barbata (3.49 adet $\mathrm{m}^{-2}$ ') nın diğer yabancl ot türlerine göre il genelinde yoğun olarak görülmesinde en büyük etken bölgede kullanılan herbisitlerin özellikle geniş yapraklı yabancı otlara karşı seçilmiş olması, erken dönemde dar yapraklı yabancı otların tanınmasında yaşanılan sıkıntılar ile çoğu zaman dar yapraklıların başaklanma dönemine kadar ayırt edilemediği ve bu dönemde de buğday için herbisit kullanımının uygun olmadığından dolayı veya geç dönemde uygulanması (buğday sapa kalkmadan hemen önce) bölgede bu yabancı otların baskın olarak görülmesinin sebepleri olarak düşünülmektedir. Ayrıca Avena türlerinin tohumlarının buğdaydan önce olgunlaşarak hasat öncesinde toprağa dökmesi ve tarımsal faaliyetlerle bir yerden diğer yere taşınması yaygınlığını önemli ölçüde artırmaktadır. Özellikle de S. cereale'nin buğday üretim alanlarında yoğun olmasının üretici açısından sorun olarak görülmediği ve mücadelesine yönelik bir uygulamanın yapılmaması yoğunluğunun her geçen gün artmasına neden olmaktadır. S. cereale, $A$. barbata Pott ex Link subsp. barbata, $C$. arvensis, ve $G$. tricornutum türleri hem rastlama sıklığı hem de yoğunluk bakımından il genelinde dikkat çeken türler olup her ne kadar yoğunluk bakımından skala değerine göre orta 
yoğunlukta yer alsa da rastlama sıklığı bakımından çok yaygın türleri oluşturmaktadır. $\mathrm{Bu}$ durum söz konusu bu türlerin her iki tarladan birinde görülmesine ve mücadelesinin yapılmadığı durumlarda toprakta ilerleyen yıllarda tohum rezervindeki artış ile yoğunluklarının zamanla artacağını göstermektedir. Bu türlerin bölgede buğdayda sık görülmesi ileriki dönemlerde dikkatle izlenmesi gerektiğini vurgulamaktadır. Ancak kullanılan çeşit, yapılacak olan ekim nöbeti sistemi, erken dönemde etkili yabancı ot kontrolü ve iklim koşullarına bağlı olarak yıldan yıla türlerin yoğunluğunda farklılıkların gözlemlenebileceği birçok çalışmada da belirtilmiştir. Buğday üretim sezonunda ilin hakim olduğu iklim koşulları özellikle de düşük

\section{Sonuç ve Öneriler}

Uşak ili buğday ekim alanlarında yabancı otların tür ve yoğunlukların belirlenmesine yönelik yapılan çalışma bölge için ilk kayıtları oluşturmakta ve izlenecek olan kontrol yöntemleri ile türler hakkında önemli verileri sağlamaktadır. Verim ve kaliteyi etkileyen yabancı otların türlerinin ve yoğunluklarının belirlenmesi bölge için önemli türleri ve ileri süreçte risk oluşturabilecek türlerin ortaya konulması ayrıca mücadelesine yönelik çalışmaların geliştirilmesi açısından önem taşımaktadır. Bölgede yabancı ot türlerinin çok yoğun olmadığı ancak yaygınlık açısından $S$. cereale, A. barbata Pott ex Link subsp. barbata, $C$. arvensis, $G$. tricortunum ve $B$. radians türlerinin ilk sıralarda yer aldığı, yaygınlık ve yoğunlukların dolayısıyla da baskın türlerin ilçeler bakımından kısmen de olsa farklılık gösterdiği tespit edilmiştir. Rastlama sıklığı bakımından Uşak ilinde $S$. cereale ve $C$. arvensis dikkati çekerken, yoğunluk bakımından $S$. cereale ve $A$. barbata Pott ex Link subsp. barbata ilk sırada yer almıştır. Ülkemizde farklı bölgelerde de buğday alanlarının önemli bir yabancı otu olan $S$. cereale rastlama sıklığı ve yoğunluğu bakımından ilimiz koşullarında ilk sıcaklıklar erken dönemde yabancı ot kontrolünü sınırlandıran en önemli faktör olarak düşünülmektedir. Yağışlardan veya düşük sıcaklıklardan dolayı tarlaya girişte zorlanan üretici genel olarak mücadeleyi geç döneme bırakmakta ve çoğu zamanda kimyasal mücadeleyi erteleyerek başaklanma döneminde dar yapraklı yabancı otlarla karşılaşmaktadır. Buğday ekim alanlarındaki yabancı otların belirlenmesine yönelik yapılan çalışmalar sonucunda, ekolojik faktörlerin ve bu faktörlere bağlı olarak yıllara göre türlerin yaygınlık ve yoğunluklarında değişkenlik göstermesi, toprak yapısı ve yapılan tarımsal faaliyetler gibi birçok faktöre bağlı olarak yabancı otlarda çeşitliliği ortaya çıkarabilmektedir.

sırada yer almıştır. Söz konusu türlerin yaygınlığına bağlı olarak etkili kontrol yöntemleri erken dönemde uygulanmadığı ve kültürel faaliyetlerle tohum taşınımına dikkat edilmediği takdirde gelecek dönemlerde yabancı ot sorunu artarak önemli verim kayıplarının yaşanmasına zemin oluşturacaktır. Buğday ekimi sık yapılan bir kültür bitkisi olması nedeniyle yabancı ot kontrolünde kültürel önlemlerin önemi büyüktür. Bu nedenle temiz tohumluk, rekabeti yüksek çeşitler ve ekim nöbeti gibi kültürel faaliyetlerin yabancı ot populasyonlarının azaltılmasında katkısı göz ardı edilemez. Buğday ekim alanlarında, çıkış sonrasında yabancı ot mücadelesinin yalnızca kültürel yöntemlerle sürdürülmesi yabancı ot kontrolünü sağlamakta yetersiz kalmakta, bu nedenle kültürel pratiklere ek olarak kimyasal mücadele ön plana çıkmaktadır. Bu nedenle ilk adım bölgedeki yabancı ot türlerinin yaygınlık ve yoğunluklarının belirlenmesi ve bu sayede elde edilen sonuçlar doğrultusunda mücadele stratejilerinin geliştirilmesi gerekmektedir. Ayrıca bölge üreticilerinin kimyasal mücadele ve özellikle de uygulama zamanı konusunda bilinçlendirilmesi, hedef yabancı otlara uygun zamanda uygun herbisit seçiminde fayda sağlayacaktır. 
Türk Tarım ve Doğa Bilimleri Dergisi 7(2): 349-367, 2020

Çizelge 4. Uşak ili buğday ekim alanlarında görülen yabancı ot türleri, rastlama sıklıkları ve yoğunlukları.

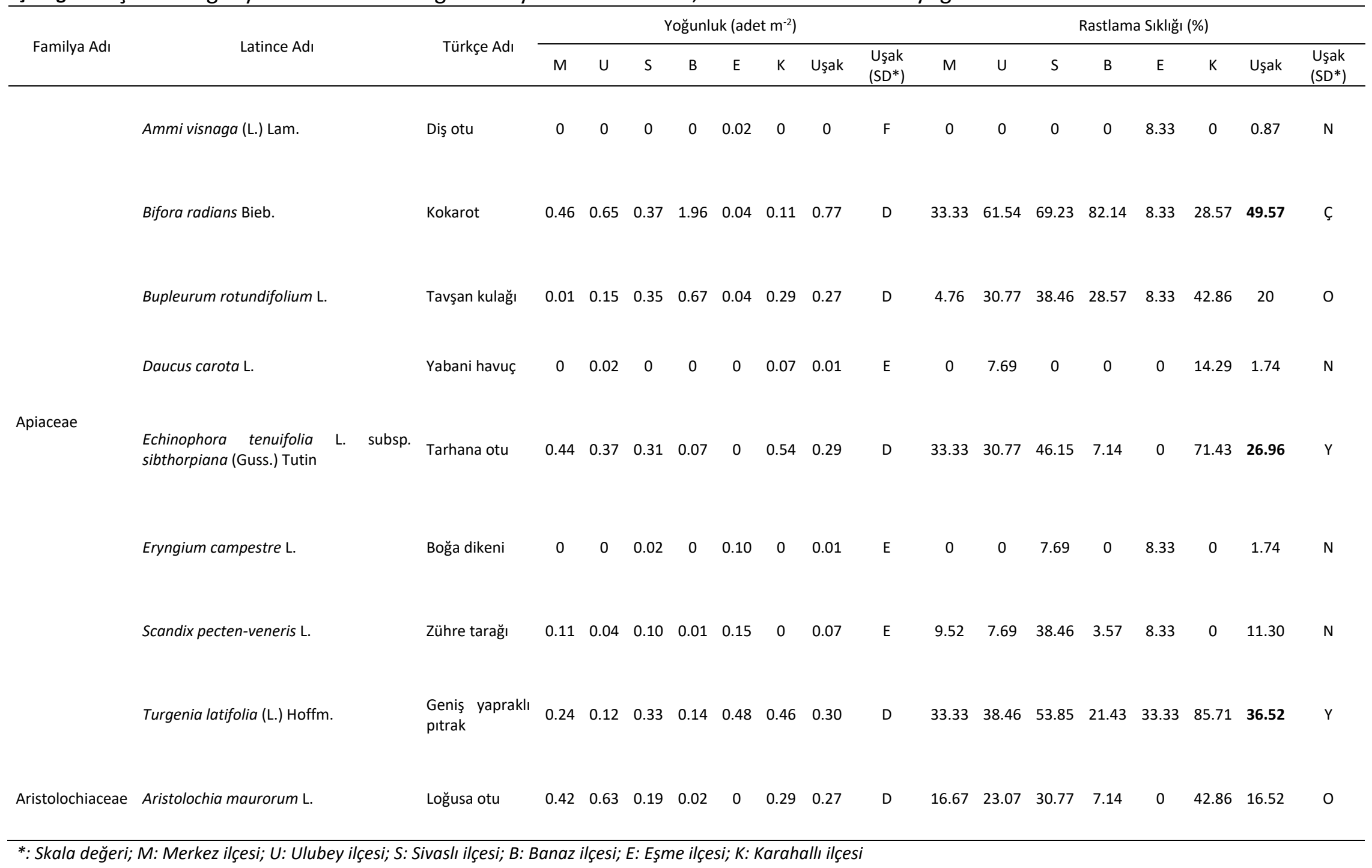


Türk Tarım ve Doğa Bilimleri Dergisi 7(2): 349-367, 2020

\section{Çizelge 4 (devamı)}

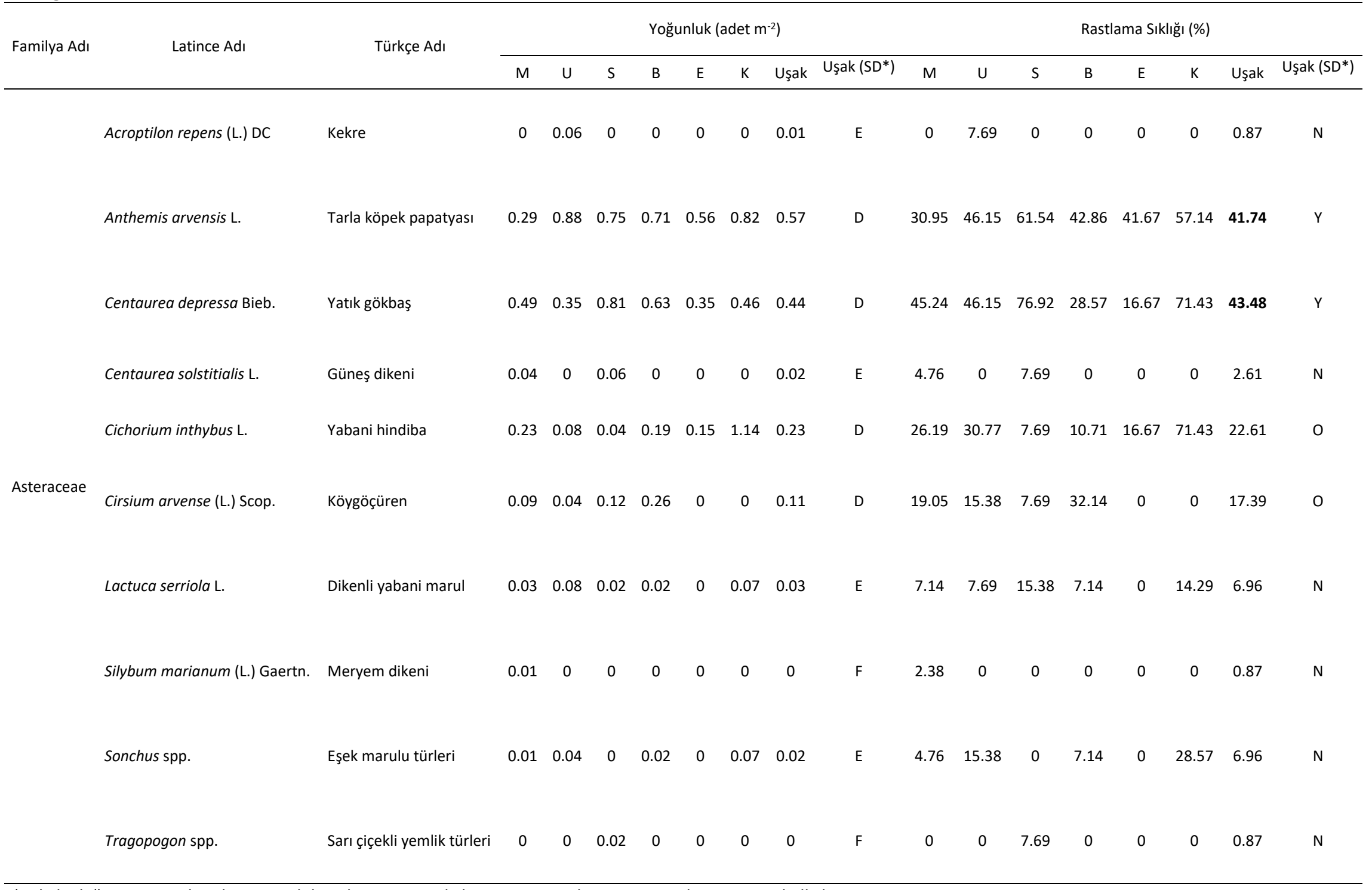

*: Skala değeri; M: Merkez ilçesi; U: Ulubey ilçesi; S: Sivasıı ilçesi; B: Banaz ilçesi; E: Eşme ilçesi; K: Karahallı ilçesi 
Türk Tarım ve Doğa Bilimleri Dergisi 7(2): 349-367, 2020

Çizelge 4 (devamı)

\begin{tabular}{|c|c|c|c|c|c|c|c|c|c|c|c|c|c|c|c|c|c|c|}
\hline \multirow{3}{*}{ Familya Adı } & \multirow{3}{*}{ Latince Adı } & \multirow{3}{*}{ Türkçe Adı } & \multicolumn{8}{|c|}{ Yoğunluk (adet $\mathrm{m}^{-2}$ ) } & \multicolumn{8}{|c|}{ Rastlama Sıklığı (\%) } \\
\hline & & & & & & & & & & Uşak (SD*) & & & & & & & & Uşak (SD*) \\
\hline & & & $\mathrm{M}$ & $u$ & $\mathrm{~S}$ & B & $\mathrm{E}$ & K & Uşak & & M & $u$ & $\mathrm{~S}$ & B & $E$ & K & Uşak & \\
\hline \multirow{3}{*}{ Boraginaceae } & Anchusa azurea Mill. & İtalyan sığır dili & 0.07 & 0.04 & 0.04 & 0.16 & 0 & 0.25 & 0.09 & $\mathrm{E}$ & 14.29 & 15.38 & 7.69 & 14.29 & 0 & 71.43 & 15.65 & 0 \\
\hline & Buglossoides arvensis (L.) I.M.Johnst. & Taşkesen otu & 0 & 0 & 0 & 0.04 & 0 & 0 & 0.01 & $\mathrm{E}$ & 0 & 0 & 0 & 10.71 & 0 & 0 & 2.61 & N \\
\hline & Myosotis sylvatica Hoffm. & Unutmabeni çiçeği & 0 & 0.02 & 0 & 0 & 0 & 0 & 0 & $\mathrm{~F}$ & 0 & 7.69 & 0 & 0 & 0 & 0 & 0.87 & $\mathrm{~N}$ \\
\hline \multirow{6}{*}{ Brasssicaceae } & Capsella bursa-pastoris (L.) Medik. & Çoban çantası & 0 & 0.06 & 0.04 & 0.29 & 0.04 & 0 & 0.84 & D & 0 & 23.08 & 7.69 & 10.71 & 8.33 & 0 & 6.09 & $\mathrm{~N}$ \\
\hline & Cardaria draba (L.) Desv. & Yabani tere & 0 & 0 & 0 & 0.01 & 0 & 0 & 0 & $\mathrm{~F}$ & 0 & 0 & 0 & 3.57 & 0 & 0 & 0.87 & $\mathrm{~N}$ \\
\hline & Descuriania sophia (L.)Webb ex Prantl. & Uzun süpürge otu & 0.03 & 0.04 & 0.19 & 0.06 & 0 & 0.07 & 0.07 & $\mathrm{E}$ & 7.14 & 15.38 & 46.15 & 7.14 & 0 & 28.57 & 13.04 & 0 \\
\hline & Lepidium draba L. & Diğnik (Diken tere) & 0.03 & 0 & 0 & 0 & 0.10 & 0.07 & 0.03 & E & 7.14 & 0 & 0 & 0 & 8.33 & 14.29 & 4.35 & $\mathrm{~N}$ \\
\hline & Myagrum perfoliatum L. & Gönül hardalı & 0.01 & 0 & 0 & 0 & 0 & 0 & 0 & $\mathrm{~F}$ & 2.38 & 0 & 0 & 0 & 0 & 0 & 0.87 & $\mathrm{~N}$ \\
\hline & Neslia paniculata (L.).Desv. & Toplu iğne hardalı & 0.01 & 0.08 & 0.21 & 0.12 & 0.06 & 0.29 & 0.10 & D & 2.38 & 30.77 & 46.15 & 14.29 & 8.33 & 57.14 & 17.39 & 0 \\
\hline
\end{tabular}

*: Skala değeri; M: Merkez ilçesi; U: Ulubey ilçesi; S: Sivaslı ilçesi; B: Banaz ilçesi; E: Eşme ilçesi; K: Karahallı ilçesi 
Türk Tarım ve Doğa Bilimleri Dergisi 7(2): 349-367, 2020

\begin{tabular}{|c|c|c|c|c|c|c|c|c|c|c|c|c|c|c|c|c|c|c|}
\hline \multirow{2}{*}{ Familya Adı } & \multirow{2}{*}{ Latince Adı } & \multirow{2}{*}{ Türkçe Adı } & \multicolumn{8}{|c|}{ Yoğunluk (adet m²) } & \multicolumn{8}{|c|}{ Rastlama Sıklığı (\%) } \\
\hline & & & M & $u$ & S & B & $\mathrm{E}$ & K & Uşak & $\begin{array}{l}\text { Uşak } \\
\text { (SD*) }\end{array}$ & M & U & S & B & $E$ & K & Uşak & $\begin{array}{l}\text { Uşak } \\
\text { (SD*) }\end{array}$ \\
\hline \multirow{4}{*}{ Brasssicaceae } & Raphanus raphanistrum L. & Yabani turp & 0.01 & 0 & 0 & 0 & 0 & 0 & 0 & $\mathrm{~F}$ & 2.38 & 0 & 0 & 0 & 0 & 0 & 0.87 & $\mathrm{~N}$ \\
\hline & Sinapis arvensis $\mathrm{L}$. & Yabani hardal & 0.29 & 0 & 0.04 & 0.19 & 0 & 0.07 & 0.16 & D & 28.57 & 0 & 15.38 & 10.71 & 0 & 14.29 & 15.65 & 0 \\
\hline & Sisymbrium altissimum L. & $\begin{array}{l}\text { Büyük bülbül } \\
\text { otu }\end{array}$ & 0.08 & 0.10 & 0.31 & 0.05 & 0.06 & 0.54 & 0.13 & D & 11.90 & 23.08 & 61.54 & 14.29 & 8.33 & 71.43 & 22.61 & 0 \\
\hline & Thlaspi arvense $\mathrm{L}$. & $\begin{array}{l}\text { Tarla akça } \\
\text { çiçeği }\end{array}$ & 0.01 & 0 & 0 & 0.01 & 0 & 0.07 & 0.01 & E & 4.76 & 0 & 0 & 3.57 & 0 & 14.29 & 3.48 & N \\
\hline Campanulaceae & $\begin{array}{l}\text { Legousia } \\
\text { (L.).Durande ex Vill. }\end{array}$ & Kadın aynası & 0.02 & 0 & 0.02 & 0 & 0.06 & 0.04 & 0.02 & E & 7.14 & 0 & 15.38 & 0 & 8.33 & 28.57 & 6.09 & N \\
\hline \multirow{3}{*}{ Caryophyllaceae } & Agrostemma githago L. & Karamuk & 0.01 & 0 & 0.02 & 0.04 & 0.21 & 0.11 & 0.05 & E & 4.76 & 0 & 7.69 & 14.29 & 41.67 & 14.29 & 11.30 & N \\
\hline & Silene vulgaris (Moench) Garcke & Adi nakıl & 0 & 0.02 & 0.04 & 0 & 0 & 0 & 0.01 & E & 0 & 7.69 & 7.69 & 0 & 0 & 0 & 1.74 & $\mathrm{~N}$ \\
\hline & Vaccaria pyramidata Medık. & Arap baklası & 0.12 & 0.02 & 0.46 & 0 & 0.04 & 0.32 & 0.12 & D & 19.05 & 7.69 & 46.15 & 0 & 8.33 & 57.14 & 17.39 & 0 \\
\hline
\end{tabular}


Türk Tarım ve Doğa Bilimleri Dergisi 7(2): 349-367, 2020

\begin{tabular}{|c|c|c|c|c|c|c|c|c|c|c|c|c|c|c|c|c|c|c|}
\hline \multirow[b]{2}{*}{ Familya Adı } & \multirow[b]{2}{*}{ Latince Adı } & \multirow[b]{2}{*}{ Türkçe Adı } & \multicolumn{8}{|c|}{ Yoğunluk (adet $\mathrm{m}^{-2}$ ) } & \multicolumn{8}{|c|}{ Rastlama Sıklığı (\%) } \\
\hline & & & $M$ & U & $\mathrm{s}$ & B & E & K & Uşak & $\begin{array}{l}\text { Uşak } \\
\text { (SD*) }\end{array}$ & $M$ & U & S & B & $\mathrm{E}$ & K & Uşak & $\begin{array}{l}\text { Uşak } \\
\text { (SD*) }\end{array}$ \\
\hline \multirow{2}{*}{ Chenopodiaceae } & Atriplex spp. & $\begin{array}{l}\text { Karapazı } \\
\text { türleri }\end{array}$ & 0.01 & 0 & 0 & 0 & 0 & 0 & 0.22 & D & 2.38 & 0 & 0 & 0 & 0 & 0 & 0.87 & N \\
\hline & $\begin{array}{l}\text { Chenopodium } \\
\text { album L. }\end{array}$ & Sirken & 0.06 & 0 & 0 & 0 & 0 & 0 & 0.02 & E & 2.38 & 0 & 0 & 0 & 0 & 0 & 0.87 & $\mathrm{~N}$ \\
\hline \multirow[b]{2}{*}{ Convolvulaceae } & $\begin{array}{l}\text { Convolvulus } \\
\text { arvensis L. }\end{array}$ & $\begin{array}{l}\text { Tarla } \\
\text { sarmaşığı }\end{array}$ & 2.49 & 2.06 & 4.15 & 1.08 & 1.46 & 4.25 & 2.28 & C & 85.71 & 92.31 & 92.31 & 78.57 & 58.33 & 100 & 83.48 & ç \\
\hline & $\begin{array}{l}\text { Convolvulus } \\
\text { galacticus L. }\end{array}$ & $\begin{array}{l}\text { Boz tarla } \\
\text { sarmaşığı }\end{array}$ & 0.29 & 0.52 & 0.12 & 0.09 & 0 & 1.32 & 0.28 & D & 14.29 & 23.08 & 7.69 & 10.71 & 0 & 28.57 & 13.04 & 0 \\
\hline Equisetaceae & $\begin{array}{l}\text { Equisetum } \\
\text { arvense } \mathrm{L} .\end{array}$ & $\begin{array}{l}\text { Tarla at } \\
\text { kuyruğu }\end{array}$ & 0 & 0 & 0 & 0.13 & 0 & 0 & 0.03 & $\mathrm{E}$ & 0 & 0 & 0 & 10.71 & 0 & 0 & 2.61 & $\mathrm{~N}$ \\
\hline \multirow[t]{3}{*}{ Euphorbiaceae } & Euphorbia spp. & $\begin{array}{l}\text { Sütleğen } \\
\text { türleri }\end{array}$ & 0.01 & 0 & 0 & 0 & 0 & 0.11 & 0.01 & E & 2.38 & 0 & 0 & 0 & 0 & 28.57 & 2.61 & $\mathrm{~N}$ \\
\hline & $\begin{array}{l}\text { Coronilla } \\
\text { scorpioides (L.) } \\
\text { W.D.J.Koch. }\end{array}$ & $\begin{array}{l}\text { Akrep } \\
\text { kuyruğu }\end{array}$ & 0.01 & 0 & 0.06 & 0.05 & 0 & 0 & 0.02 & E & 4.76 & 0 & 15.38 & 10.71 & 0 & 0 & 6.09 & $\mathrm{~N}$ \\
\hline & $\begin{array}{l}\text { Medicago } \\
\text { sativa L. }\end{array}$ & $\begin{array}{l}\text { Kültür } \\
\text { yoncası }\end{array}$ & 0 & 0 & 0 & 0 & 0.08 & 0 & 0.01 & E & 0 & 0 & 0 & 0 & 8.33 & 0 & 0.87 & $\mathrm{~N}$ \\
\hline \multirow[t]{3}{*}{ Fabaceae } & $\begin{array}{l}\text { Melilotus } \\
\text { officinalis (L.) } \\
\text { Desr. }\end{array}$ & $\begin{array}{l}\text { Kokulu sarı } \\
\text { yonca }\end{array}$ & 0.01 & 0 & 0 & 0.04 & 0 & 0.25 & 0.03 & $\mathrm{E}$ & 2.38 & 0 & 0 & 7.14 & 0 & 28.57 & 4.35 & N \\
\hline & $\begin{array}{l}\text { Vicia } \\
\text { narbonensis L. }\end{array}$ & Kaba fiğ & 0 & 0 & 0 & 0.01 & 0 & 0 & 0 & $\mathrm{~F}$ & 0 & 0 & 0 & 3.87 & 0 & 0 & 0.87 & $\mathrm{~N}$ \\
\hline & Vicia spp. & Yabani fiğ & 0.13 & 0.02 & 0.13 & 0.30 & 1.81 & 0.11 & 0.33 & D & 28.57 & 7.69 & 23.08 & 32.14 & 58.33 & 28.57 & 29.57 & $Y$ \\
\hline
\end{tabular}

*: Skala değeri; M: Merkez ilçesi; U: Ulubey ilçesi; S: Sivasıı ilçesi; B: Banaz ilçesi; E: Eşme ilçesi; K: Karahallı ilçesi 
Türk Tarım ve Doğa Bilimleri Dergisi 7(2): 349-367, 2020

\begin{tabular}{|c|c|c|c|c|c|c|c|c|c|c|c|c|c|c|c|c|c|c|}
\hline \multirow{2}{*}{ Familya Adı } & \multirow{2}{*}{ Latince Adı } & \multirow{2}{*}{ Türkçe Adı } & \multicolumn{8}{|c|}{ Yoğunluk (adet m²) } & \multicolumn{8}{|c|}{ Rastlama Sıklığı (\%) } \\
\hline & & & $\mathrm{M}$ & U & S & B & $\mathrm{E}$ & K & Uşak & $\begin{array}{l}\text { Uşak } \\
\left(S D^{*}\right)\end{array}$ & M & $u$ & s & B & E & K & Uşak & $\begin{array}{l}\text { Uşak } \\
\text { (SD*) }\end{array}$ \\
\hline \multirow[t]{2}{*}{ Geraniaceae } & $\begin{array}{l}\text { Geranium } \\
\text { tuberosum L. }\end{array}$ & Turna gagası & 0 & 0.02 & 0 & 0.10 & 0 & 0.11 & 0.03 & $\mathrm{E}$ & 0 & 7.69 & 0 & 14.29 & 0 & 42.86 & 6.96 & $\mathrm{~N}$ \\
\hline & $\begin{array}{l}\text { Lamium } \\
\text { amplexicaule L. }\end{array}$ & Ballıbaba & 0 & 0.12 & 0 & 0.03 & 0 & 0 & 0.02 & $\mathrm{E}$ & 0 & 15.38 & 0 & 7.14 & 0 & 0 & 3.48 & $\mathrm{~N}$ \\
\hline \multicolumn{19}{|l|}{ Lamiaceae } \\
\hline & $\begin{array}{l}\text { Wiedemmania } \\
\text { orientalis Fisch. Et } \\
\text { Mey. }\end{array}$ & $\begin{array}{l}\text { Doğu } \\
\text { ballıbabası }\end{array}$ & 0.49 & 0.04 & 0.62 & 0.01 & 0 & 0.04 & 0.26 & D & 16.67 & 15.38 & 84.62 & 3.57 & 0 & 14.29 & 18.26 & 0 \\
\hline Liliaceae & $\begin{array}{l}\text { Ornithogalum } \\
\text { umbellatum } \mathrm{L} .\end{array}$ & Tükrük otu & 0 & 0 & 0.02 & 0.04 & 0 & 0 & 0.01 & $\mathrm{E}$ & 0 & 0 & 7.69 & 10.71 & 0 & 0 & 3.48 & $\mathrm{~N}$ \\
\hline \multirow[t]{3}{*}{ Malvaceae } & Malva sylvestris $\mathrm{L}$. & $\begin{array}{l}\text { Yabani } \\
\text { ebegümeci }\end{array}$ & 0.01 & 0 & 0 & 0 & 0 & 0 & 0 & $\mathrm{~F}$ & 2.38 & 0 & 0 & 0 & 0 & 0 & 0.87 & $\mathrm{~N}$ \\
\hline & $\begin{array}{l}\text { Fumaria officinalis } \\
\text { L. }\end{array}$ & $\begin{array}{l}\text { Hakiki } \\
\text { şahdere }\end{array}$ & 0 & 0 & 0 & 0.03 & 0 & 0 & 0.01 & $\mathrm{E}$ & 0 & 0 & 0 & 7.14 & 0 & 0 & 1.74 & N \\
\hline & $\begin{array}{l}\text { Glaucium } \\
\text { corniculatum } \\
\text { Rudolph }\end{array}$ & $\begin{array}{l}\text { Kırmızı } \\
\text { boynuzlu } \\
\text { gelincik }\end{array}$ & 0 & 0.31 & 0 & 0 & 0 & 0.07 & 0.04 & E & 0 & 38.46 & 0 & 0 & 0 & 14.29 & 5.22 & N \\
\hline \multicolumn{19}{|l|}{ Papaveraceae } \\
\hline & $\begin{array}{l}\text { Hypecoum } \\
\text { procumbens } \mathrm{L} .\end{array}$ & $\begin{array}{l}\text { Adi boynuzlu } \\
\text { kimyon }\end{array}$ & 0.02 & 0.02 & 0.02 & 0 & 0 & 0 & 0.01 & $\mathrm{E}$ & 4.76 & 7.69 & 15.38 & 0 & 0 & 0 & 3.48 & $\mathrm{~N}$ \\
\hline & Papaver rhoeas L. & Gelincik & 0.34 & 0.73 & 0.06 & 0,34 & 0.13 & 0.43 & 0.33 & D & 45.24 & 61.54 & 23.08 & 50 & 25 & 57.14 & 45.22 & Y \\
\hline
\end{tabular}

*: Skala değeri; M: Merkez ilçesi; U: Ulubey ilçesi; S: Sivaslı ilçesi; B: Banaz ilçesi; E: Eşme ilçesi; K: Karahallı ilçesi 


\begin{tabular}{|c|c|c|c|c|c|c|c|c|c|c|c|c|c|c|c|c|c|c|}
\hline \multirow{2}{*}{ Familya Adı } & \multirow{2}{*}{ Latince Adı } & \multirow{2}{*}{ Türkçe Adı } & \multicolumn{8}{|c|}{ Yoğunluk (adet m²) } & \multicolumn{8}{|c|}{ Rastlama Sıklığı (\%) } \\
\hline & & & M & $u$ & s & B & E & K & Uşak & $\begin{array}{l}\text { Uşak } \\
\text { (SD*) }\end{array}$ & M & $u$ & S & B & E & K & Uşak & $\begin{array}{l}\text { Uşak } \\
\text { (SD*) }\end{array}$ \\
\hline \multirow{8}{*}{ Poaceae } & Aegilops spp. & Buğday anası & 0 & 0.44 & 0 & 0 & 0 & 0 & 0.05 & E & 0 & 7.69 & 0 & 0 & 0 & 0 & 0.87 & $\mathrm{~N}$ \\
\hline & Alopecurus myosuroides Huds. & Tilki kuyruğu & 0.08 & 0 & 0 & 1.24 & 0.04 & 0 & 0.33 & $\mathrm{D}$ & 7.14 & 0 & 0 & 14.29 & 8.33 & 0 & 6.96 & $\mathrm{~N}$ \\
\hline & $\begin{array}{l}\text { Avena barbata Pott ex Link subsp. } \\
\text { barbata }\end{array}$ & Narin yulaf & 3.35 & 4.79 & 3.13 & 3.55 & 4.17 & 0.36 & 3.49 & C & 76.19 & 76.92 & 76.92 & 85.71 & 75 & 57.14 & 77.39 & Ç \\
\hline & Bromus spp. & İbubukotu & 0.15 & 0.02 & 0.52 & 0.14 & 0 & 0.29 & 0.17 & $\mathrm{D}$ & 7.14 & 7.69 & 15.38 & 10.71 & 0 & 14.28 & 8.70 & $\mathrm{~N}$ \\
\hline & Hordeum murinum L. & Duvar arpası & 0.01 & 0 & 0 & 0.05 & 0 & 0 & 0.02 & E & 2.38 & 0 & 0 & 3.57 & 0 & 0 & 1.74 & $\mathrm{~N}$ \\
\hline & Lolium spp. & Delice & 0.02 & 0.02 & 0.29 & 0.38 & 0.25 & 0 & 0.17 & $\mathrm{D}$ & 2.38 & 7.69 & 15.38 & 10.71 & 33.33 & 0 & 9.57 & $\mathrm{~N}$ \\
\hline & $\begin{array}{l}\text { Phragmites australis (Cav.) Trin. ex } \\
\text { Steud. }\end{array}$ & Kamış & 0 & 0 & 0 & 0.16 & 0.10 & 0 & 0.05 & $\mathrm{E}$ & 0 & 0 & 0 & 3.57 & 8.33 & 0 & 1.74 & $N$ \\
\hline & Secale cereale $\mathrm{L}$. & Çavdar & 2.88 & 2.23 & 5 & 2.75 & 7.44 & 10.89 & 3.98 & C & 88.10 & 61.54 & 100 & 85.71 & 83.33 & 85.71 & 85.22 & Ç \\
\hline \multirow{3}{*}{ Polygonaceae } & Polygonum aviculare L. & Çoban değneği & 0.20 & 1.67 & 0.06 & 0.44 & 0.77 & 1.18 & 0.53 & $\mathrm{D}$ & 19.05 & 69.23 & 15.38 & 17.86 & 41.67 & 57.14 & 28.70 & Y \\
\hline & Polygonum convolvulus L. & $\begin{array}{l}\text { Sarmaşık } \\
\text { değneği }\end{array}$ & 0.10 & 0 & 0.04 & 0.13 & 1.63 & 0.07 & 0.25 & D & 19.05 & 0 & 7.69 & 3.57 & 33.33 & 14.29 & 13.04 & 0 \\
\hline & Rumex spp. & Labada & 0.02 & 0 & 0.04 & 0.01 & 0 & 0 & 0.01 & $\mathrm{E}$ & 4.76 & 0 & 15.38 & 3.57 & 0 & 0 & 4.35 & $\mathrm{~N}$ \\
\hline
\end{tabular}

*: Skala değeri; M: Merkez ilçesi; U: Ulubey ilçesi; S: Sivaslı ilçesi; B: Banaz ilçesi; E: Eşme ilçesi; K: Karahallı ilçesi 
Türk Tarım ve Doğa Bilimleri Dergisi 7(2): 349-367, 2020

\section{Çizelge 4 (devamı)}

\begin{tabular}{|c|c|c|c|c|c|c|c|c|c|c|c|c|c|c|c|c|c|c|}
\hline \multirow{2}{*}{ Familya Adı } & \multirow{2}{*}{ Latince Adı } & \multirow{2}{*}{ Türkçe Adı } & \multicolumn{8}{|c|}{ Yoğunluk (adet m²) } & \multicolumn{8}{|c|}{ Rastlama Sıklığı (\%) } \\
\hline & & & $\mathrm{M}$ & U & $\mathrm{S}$ & B & $\mathrm{E}$ & K & Uşak & $\begin{array}{l}\text { Uşak } \\
\left(S D^{*}\right)\end{array}$ & $M$ & U & $\mathrm{S}$ & B & $\mathrm{E}$ & K & Uşak & $\begin{array}{l}\text { Uşak } \\
\left(S D^{*}\right)\end{array}$ \\
\hline \multirow[t]{4}{*}{ Primulaceae } & Anagallis arvensis $\mathrm{L}$. & Fare kulağı & 0 & 0.04 & 0 & 0.02 & 0 & 0 & 0.01 & & 0 & 7.69 & 0 & 7.14 & 0 & 0 & 2.61 & \\
\hline & & & & & & & & & & $\mathrm{E}$ & & & & & & & & $\mathrm{N}$ \\
\hline & Adonis aestivalis $\mathrm{L}$. & Kan damlası & 0.05 & 0 & 0.04 & 0.01 & 0 & 0 & 0.03 & & 2.38 & 0 & 15.38 & 3.57 & 0 & 0 & 3.48 & \\
\hline & & & & & & & & & & $E$ & & & & & & & & $\mathrm{~N}$ \\
\hline \multirow[t]{4}{*}{ Ranunculaceae } & Consolida orientalis (J.Gay) & Doğu tarla & 0.27 & 0.31 & 0.10 & 0.36 & 0 & 0 & 0.23 & & 23.81 & 38.46 & 23.08 & 28.57 & 0 & 0 & 23.48 & \\
\hline & Schrödinger & hazeranı & & & & & & & & D & & & & & & & & 0 \\
\hline & Ranunculus arvensis $\mathrm{L}$. & Mustafa çiçeği & 0.28 & 0 & 0.06 & 0.09 & 0.02 & 0 & 0.13 & & 16.67 & 0 & 15.38 & 21.43 & 8.33 & 0 & 13.91 & \\
\hline & & & & & & & & & & D & & & & & & & & 0 \\
\hline \multirow[t]{2}{*}{ Resedaceae } & Reseda lutea $\mathrm{L}$. & Muhabbet çiçeği & 0.25 & 0.17 & 0.13 & 0.01 & 0 & 0.29 & 0.15 & & 23.81 & 46.15 & 30.77 & 3.57 & 0 & 42.86 & 20.87 & \\
\hline & Asperula arvensis $\mathrm{L}$. & Tarla yapışkan otu & 0 & 0.02 & 0 & 0.11 & 0 & 0.11 & 0.03 & $\mathrm{E}$ & 0 & 7.69 & 0 & 17.86 & 0 & 14.29 & 6.09 & $\mathrm{~N}$ \\
\hline \multicolumn{19}{|l|}{ Rubiaceae } \\
\hline & Galium tricornutum Dandy & Yoğurt otu & 1.60 & 2.62 & 1.79 & 1.29 & 3.31 & 1.82 & 1.88 & C & 57.14 & 53.85 & 76.92 & 64.29 & 66.67 & 42.86 & 60.87 & Ç \\
\hline & Veronica spp. & Yavşan otu & 0 & 0 & 0 & 0.03 & 0 & 0 & 0.01 & $\mathrm{E}$ & 0 & 0 & 0 & 10.71 & 0 & 0 & 2.61 & $\mathrm{~N}$ \\
\hline \multicolumn{19}{|l|}{ Scrophulariaceae } \\
\hline & Verbascum spp. & Sığır kuyruğu & 0 & 0.02 & 0 & 0 & 0 & 0.04 & 0 & $\mathrm{~F}$ & 0 & 7.69 & 0 & 0 & 0 & 14.29 & 1.74 & $\mathrm{~N}$ \\
\hline
\end{tabular}

*: Skala değeri; M: Merkez ilçesi; U: Ulubey ilçesi; S: Sivaslı ilçesi; B: Banaz ilçesi; E: Eşme ilçesi; K: Karahallı ilçesi 


\section{Teşekkür}

¥ Derya KÖKTAŞ’ın yüksek lisans tezinden üretilmiştir.

\section{Kaynaklar}

Anonim, 2018a. Uşak Belediyesi Coğrafi Yapısı. (http:// http://www.usak.bel.tr) (Erişim Tarihi: 10.11.2018).

Anonim, 2018b. T.C. Başbakanlık Devlet Meteoroloji İşleri Genel Müdürlüğü, Uşak il Müdürlüğü Kayıtları.

Arslan, Z.F. 2018a. Şanlıurfa ili mısır tarlalarında bulunan yabancı otların yaygınlık ve yoğunlukları ile mücadele sorunlarına çözüm önerileri. Türk Tarım-Gıda Bilim ve Teknoloji Dergisi, 6(10): 1322-1328. ISSN: 2148-127X.

Arslan, Z.F. 2018b. Decrease in biodiversity in wheat fields due to changing agricultural practices in five decades. Biodiversity and Conservation. 27(12):3267-3286.

Bilgir, S. 1965. Ege Bölgesi hububat tarlalarında görülen yabancı otlar ve savaş imkanları üzerinde bazı incelemeler. T.C. Tarım Bakanlığı Yayınları Teknik Bülteni No: 14, İzmir.

Boz, Ö. 2000. Aydın ili buğday ekim alanlarında bulunan yabancı otlar ile rastlama sıklıkları ve yoğunluklarının saptanması. Türkiye Herboloji Dergisi, 3 (2): 1-11.

Boz, Ö., Doğan, N.M., Dura, S. 2000. Denizli ili buğday ekim alanlarında bulunan yabancı otlar ile rastlanma sıklıkları ve yoğunluklarının saptanması. Türkiye Herboloji Dergisi, 3 (1): 37-52.

Boz, Ö., Doğan, N., Albay, F. 2002. Aydın ili buğday alanlarındaki önemli yabancı otlar ve mücadelesi. Tarım ve Köy İşleri Bakanlığı Aydın il Müdürlüğü Dergisi, 24-27.

Bükün, B. 2004. The weed flora of winter wheat in Şanlıurfa, Turkey. Pakistan Journal of Biological Sciences, 7 (9):1530-1534.

Cavlan, S., Şık, L. 2012. Flora of Üçpınar Town (Manisa-Turkey). Celal Bayar University Journal of Science, 8:1-16.

Civelek, Ş., Kırbağ, S., Parlak, Y. 1997. Elazığ ilii tahıl tarlalarındaki yabancı otların belirlenmesi. Türkiye II. Herboloji Kongresi, 1-4 Eylül 1997, İzmir, 53.

Çetin, E., Seçmen, Ö. 2008. Flora of Boncuk Mountains (Burdur-Muğla, Turkey), International Journal of Botany 4 (2): 130-150.

Davis, P.H. (ed) 1965-1985. Flora of Turkey and the Aegean Islands. Vol 1-9. University Press, Edingburg.
Davis, P.H., Mill, R., Tan, K. 1988. Flora of Turkey and the East Aegean Islands. Vol 10. University Press, Edingburg.

Doğan, Y., Baslar, S., Çelik, A., Mert, H.H., Öztürk, M. 2004. A study on the roadside plants of West Anatolia, Turkey. Nat. Croat., 13: 63-80.

Ersoy, Y., Çıngay. B., Şekerciler, F., Demir, O., Cabi, E. 2019. Checklist of grasses (Poaceae Barn.) in Istanbul. Acta Biologica Turcica, 32 (3): 149159.

FAOSTAT, 2018. Wheat Production in World 2018. (http://www.fao.org) (Erişim Tarihi: 11.06.2019).

Fener, D., Aykurt, C. 2019. The flora of Kıbrıs River wildlife development area (KaşAntalya/Turkey). Biological Diversity and Conservation, 12(1): 107-121.

Gider, P.Z. 2013. İstilacı Bitki Türlerinin ve İstila Yeteneklerinin Tek Yıllık Otlaklarda ve Yol Kenarlarında (Aydın, Denizli, Muğla, İzmir) Belirlenmesi. Adnan Menderes Üniversitesi Fen Bilimleri Enstitüsü, Yüksek Lisans Tezi, Aydın.

Gökalp, Ö., Üremiş, i. 2015. Mardin buğday ekim alanlarında bulunan yabancı ot türlerinin, yaygınlıklarının ve yoğunluklarının belirlenmesi. Mustafa Kemal Üniversitesi Ziraat Fakültesi Dergisi, 20 (1):13-22.

Güler, B., Kesim, İ., Uğurlu, E. 2013. Flora of Dervişli (Eşme, Uşak/Turkey) and its surroundings. Biological Diversity and Conservation, 6 (1):169-177.

Güncan, A. 1982. Erzurum yöresinde buğday ürününe karışan bazı yabancı ot tohumlarının çimlenme biyolojisi üzerinde araştırmalar. Atatürk Üniversitesi Yayınları, Erzurum, $589 \mathrm{~s}$.

Güner, A., Özhatay. N., Ekim. T., Başer. K.H.C. (eds) 2000. Flora of Turkey and the Aegean Islands. Vol 11, Supplement 2, Edinburg University Press, Edingburgh (GB), 656p.

Gürbüz, R., Uygur, S., Uygur, N. 2018. Ağrı ili buğday ekim alanlarında segetal floranın belirlenmesi. Turkish Journal of Weed Science, 21(1):2018:8-18.

Holm, F.A., Kirkland, K.J., Stevenson, F.C. 2000. Defining optimum herbicide rates and timing for wild oat (Avena fatua) control in spring wheat (Triticum aestivum). Weed Technology, 14: 167-175.

Kadıoğlu, i. 1989. Çukurova bölgesi buğday ekiliş alanlarında görülen yabani yulaf (Avena spp.) türleri, gelişme biyolojileri, buğday ile karşııklı 
etkileşimleri ve kontrol olanakları üzerinde araştırmalar. Adana Zirai Mücadele Araştırma Enstitüsü Müdürlüğü Yayınları, Ankara, 66.

Kara, A. 1993. Tekirdağ ili buğday ekim alanlarında görülen önemli yabancı ot türleri, yayılışları ve bunlardan en önemlisinin biyolojisi üzerinde araştırmalar. Doktora Tezi, Ankara Üniversitesi Fen Bilimleri Enstitüsü, Ankara, 103s.

Kara, H., Dönmez, Ş. M., Ay, Ş. 2010. İklim değişikliğinin Uşak'ta tarım ürünlerine etkisi. Biyoloji Bilimleri Araştırma Dergisi, 3 (1): 3946.

Kaya, Y., Zengin, H. 2000. Pasinler Ovasındaki buğday tarlalarında sorun oluşturan yabancı otlarla, rastlama sıklıkları, hayat formları ve fitocoğrafik bölgelerinin belirlenmesi. Türkiye Herboloji Dergisi, 3(1): 17-26.

Karlıil, B. 1988. Bornova yöresindeki buğday tarlalarında görülen yabancı otların saptanması, fide ve tohum morfolojilerinin belirlenmesi üzerinde incelemeler. Yüksek Lisans Tezi, Ege Üniversitesi Fen Bilimleri Enstitüsü, $55 \mathrm{~s}$.

Khaliq, A., Matloob, A., Ahmad, N., Rasul, F., Awan, I.U. 2012. Post emergence chemical weed control in direct seeded fine rice. The Journal of Animal \& Plant Sciences, 22(4): 1018-7081.

Khan, M., Haq, N. 2002. Wheat crop yield loss assessment due to weeds. Sarhad Journal of Agriculture, 18:449-453.

Kılıç, D. D., Kutbay, H. G., Sürmen, B., Hüseyinoğlu, R. 2018. The classification of some plants subjected to disturbance factors (grazing and cutting) based on ecological strategies in Turkey. Rendiconti Lincei. Scienze Fisiche e Naturali, 29(1): 87-102.

Kireç, M., Yarcl, C. 1998. The Flora of the agricultural areas in Enez (Edirne) and environs. Turkish Jaurnal of Botany, 23: 53-62.

Kitiş, Y.E., Boz, Ö. 2003. Isparta ili buğday ekim alanlarındaki yabancı otların yaygınlık ve yoğunluklarının saptanması. Türkiye Herboloji Dergisi, 6 (1): 16-38.

Kordali, Ş., Zengin, H. 2007. Bayburt ili buğday ekim alanlarında bulunan yabancı otların rastlama sıklığı, yoğunlukları ve topluluk oluşturması durumlarının saptanması. Atatürk Üniversitesi Ziraat Fakültesi Dergisi, 38: 9-23.

Nanher, A.H., Singh, R., Tyagı, S. 2015. Effects of weed control treatments on wheat crop and associated weeds. Trends in Biosciences Journal, 8(2):421-428.
Odum, E.P. 1971. Fundamantals of Ecology. W.B. Saunders Company, Philedelphia, London, Toronto, $574 \mathrm{p}$.

Oerke, E.C. 2005. Crop losses to pests. Jaurnal of Acricultural Science, 144 (01): 31.

Önen, H., Akdeniz, M., Farooq, S., Hussain, M., Özaslan, C. 2018. Weed flora of citrus orchards and factors affecting its distribution in western mediterranean region of Turkey. Planta Daninha, 36: e018172126.

Özaslan, C., Boyraz, N., Güncan, A. 2011. Diyarbakır ili buğday ekim alanlarında sorun olan yabancı otların belirlenmesi. Türkiye IV. Bitki Koruma Kongresi Bildirileri, 28-30 Haziran, Kahramanmaraş, $139 \mathrm{~s}$.

Öztürk, M., Tatlı, A., Özçelik, H., Behçet, L. 2015. General characteristics of flora and vegetation formations of eastern anatolia region and its environs (Turkey). Süleyman Demirel University Journal of Science. 10: 23-48.

Pala, F., Mennan, H. 2017. Diyarbakır buğday tarlalarında bulunan yabancı otların belirlenmesi. Bitki Koruma Bülteni, 57(4): 447461.

Sargın, S.A., Akçiçek, E., Selvi, S. 2013. An ethnobotanical study of medicinal plants used by the local people of Alaşehir (Manisa) in Turkey. Journal of Ethnopharmacology, 150: 860-874.

Satıl, F., Tümen, G., Selvi, S. 2016. Balıkesir Üniversitesi bahçesi ve florası. Biyoloji Bilimleri Araştırma Dergisi, 9 (2): 26-32.

Sırma, M. 1995. Tokat yöresinde buğday alanlarında sorun oluşturan yabancı otlar, önemlilerinden bazılarının topluluk oluşturma durumları ve topraktan kaldırdıkları " $\mathrm{N}, \mathrm{P}, \mathrm{K}$ " miktarı üzerinde bir araştırma. Selçuk Üniversitesi, Doktora Tezi, Konya.

Sırma, M., Kadıoğlu, i. 2010. Erzincan ili-Otlukbeli ilçesi buğday ekim alanlarında saptanan önemli yabancı ot türleri, rastlanma sıklıkları ve yoğunlukları. Gaziosmanpaşa Üniversitesi, Ziraat Fakültesi Dergisi, 27(1): 27-34.

Sırrı, M. 2019. Buğday ekim alanlarında sorun oluşturan türleri: Siirt ili örneği. Türkiye Tarımsal Araştırmalar Dergisi. 6(2):142-152.

Söker, A. Koyuncu, O., Yaylacı, Ö.K., Tokur, S. 2012. Eskişehir ve çevresindeki bazı tarım alanlarındaki tarla yabancı otlarının florası. Artvin Çoruh Üniversitesi Orman Fakültesi Dergisi, 13(1):109-127.

Taştan, B., Erciş, A. 1991. Orta Anadolu Bölgesi buğday ekim alanlarında gözlenen yabancı 
otların yayılış ve yoğunlukları üzerinde araştırmalar. Bitki Koruma Bülteni, 31(1-4): 39-60.

Tepe, I. 1989. Van ve yöresinde hububat alanlarında yabancı otlar ve dağılışları. TÜBiTAK, Doğa Türk Tarım ve Ormancılık Dergisi. 13 (36): 1315-1329.

Töre, Ö. 2014. Tokat ili buğday ekim alanlarında sorun olan yabancı ot türleri ile bunların yaygınlık ve yoğunluklarının belirlenmesi. (Master's thesis, Gaziosmanpaşa University), 42p.

Tuğrul, M. 2013. Bursa ili zeytin bahçelerinde görülen önemli yabancı ot türleri, yoğunlukları ve rastlanma sıklıklarının belirlenmesi. Yüksek lisans tezi, Tekirdağ, 42s.

Tursun, N. 2002. Determination of weeds in wheat fields in Kahramanmaraş. Türkiye Herboloji Dergisi, Turkey. 5 (1): 1-11.

Türe, C., Böcük, H. 2007. An investigatin on the diversity, distribution and conservation of Poaceae species growing naturally in Eskişehir province (Central Anatolia-Turkey). Pakıstan Jaurnal of Botany, 39 (4): 1055-1070.

Türe, C., Köse, Y.B. 2000. Eskişehir ve çevresindeki bazı tarım alanlarında yayılış gösteren yabancı ot florası üzerine bir araştırma. Turkish Jaurnal Agriculture and Forestry, 24: 327-331.

TÜik, 2017a. Türkiye İstatistik Kurumu Bitkisel Üretim İstatistikleri. (https://biruni.tuik.gov.tr) (Erişim Tarihi: 31.10.2019).

TÜiK, 2017b. Türkiye İstatistik Kurumu Bitkisel Üretim İstatistikleri. (https://biruni.tuik.gov.tr) (Erişim Tarihi: 11.06.2018).

Uludağ, A. 1993. Diyarbakır yöresinde yetiştirilen buğday-mercimek kültürlerindeki önemli yabancı otların dağılışı ve bunların bazı biyolojik özellikleri üzerinde araştırmalar. (Master's thesis, Cumhuriyet University), 50p.

Uludağ, A. 1997. Weed infestation level changes in cereals in Diyarbakır, Turkey. 10th EWRS Symposium, 22-26 June 1997, Poznan, 22p.

Uygur, F.N. 1985. Untersuchungen zu art und bedeutung der verunkrautung der verunkrautung in der çukurova unter besonderer berücksictigung von Cynodon dactylon (L.) Pers. und Sorghum halepense (L.) Pers. Stuttgard. Germany, 169 s.

Uygur, S. 1997. Çukurova bölgesindeki yabancı ot türleri, bu türlerin konukçuluk ettikleri hastalık etmenleri ve dağılımları ile hastalık etmenlerinin biyolojik mücadelede kullanılma olanaklarının araştırılması. Doktora Tezi, Çukurova Üniversitesi, $148 \mathrm{~s}$.

Üstüner, T., Altın. B.N. 2003. Niğde yöresinde buğday tarlalarında sorun olan yabancı otlar ve yoğunlukları. Türkiye Herboloji Dergisi, 1 (3):32.

Wilson, B.J., Wright, K.J. 1987. Variability in the growth of cleavers (Galium aparine) and their effect on wheat yield. British Crop Protection Conference -Weeds, 1051-1105.

Yarcı, C., Altay, V. 2016. Kocaeli ve çevresindeki tarım alanlarının yabani ot florası. Erzincan Fen Bilimleri Enstitüsü Dergisi, 9 (2): 148-171.

Yıldırım, E. 2008. Tarımsal Zararlılarla Mücadele Yöntemleri ve ilaçlar. 2. Baskı. Atatürk Üniversitesi Ziraat Fakültesi Yayınları No: 219, Erzurum, $350 \mathrm{~s}$.

Zimdahl, R. L. 2013. Fundamentals of weed science. Fourth Edition Academic Press, San Diego, California, USA. 